\title{
Iğdır İli ve Yakın Çevresinin Ornito-Turizm Perspektifinde Değerlendirilmesi
}

\section{Evaluation of Igdir Province and Its Neighborhood in terms of Ornitho-Tourism Perspective}

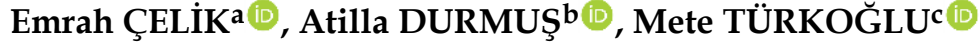

a Dr. Öğr. Üyesi, I ̆̆dır Üniversitesi, I ̆ğır Teknik Bilimler Meslek Yüksekokulu, Ormancılık Bölümü, Iğdır, Türkiye.

b Prof. Dr. Van Yüzüncü Yil Üniversitesi, Fen Fakültesi, Biyoloji Bölümü, Van, Türkiye.

c Doğa Koruma Milli Parklar Genel Müdürlüğü, 13. Bölge Müdürlüğü, Iğdır Şube Müdürlüğü, Iğdır, Türkiye.

\begin{abstract}
Özet
Kuş gözlemi, kuşlara olan ilgi ile başlayıp daha sonra doğaya karşı bir sempati duyusuyla büyüyen önemli bir faaliyettir. Doğa turizminin önemli kollarından biri olan ornito-turizm (kuş gözlemciliği), doğasever birçok katılımcının kolay ve ucuz maliyetli bir şekilde vakit geçirmesine ve doğa bilincine önemli katkı sağlamasına yardımcı olan bir etkinlik olarak göze çarpmaktadır. Türkiye illeri göz önüne alındığında, Iğdır ili, 3 ülkeye sınır olmasının yanı sıra, önemli biyolojik çeşitlilik sıcak noktaları ve önemli sulak alanları ile, hem flora hem de fauna açısından çok zengin bir potansiyele sahiptir. Batı Palaearktik zoocoğrafik bölgesinden güney-kuzey istikametinde göç eden kuşların geçiş noktasında yer alan Iğdır ili, ilkbahar ve sonbahar mevsimlerinde ornitolojik yönden oldukça aktiftir. Araştırmada aktif arazi çalışmaları ile birincil verilere, literatür taraması yapılarak da ikincil verilere ulaşılmıştır. Mevcut çalışma ile birlikte doğal güzellikleri ve kuş çeşitliliği ile dikkat çeken Iğdır İli'nin ornito-turizm (kuş gözlem turizmi) kapsamındaki önemi ortaya konulmuştur.
\end{abstract}

Anahtar Kelimeler: Avifauna, Coğrafi Bilgi Sistemleri (CBS), Iğdır, Kuş Gözlemciliği.

\begin{abstract}
Bird watching is an important activity that starts with an interest in birds and then grows with a sympathy for nature. Of the substantial known-activities of nature tourism, ornitho-tourism (birdwatching) is of the leading activities that help many naturel overs spend time easily and cheaply and make a significant contribution to natüre awareness. Considering the provinces of Turkey, the province of Igdir has a very rich potential in terms of both flora and fauna, having important biodiversity hotspots, as well as being a border to 3 countries. Due to being located at the transition point of birds migrating from the Western Palaearctic zoogeographic region in the south-north direction, Igdir province is ornithological-active in the spring and autumn seasons. In this research, the primary data is attained by active field studies and secondary data were obtained through a literature review. Along with the current study, the importance of Igdir Province, which attracts attenti on with its natural beauties and bird diversity, within the scope of ornitho-tourism (birdwatching tourism) has been revealed.
\end{abstract}

Keywords: Avifauna, Birdwatching,Geographical Information Systems (GIS), Igdir.
Makale Bilgisi

Geliş Tarihi

02.06.2021

Kabul Tarihi

21.06.2021

Sayı Editörü

Hacer Arslan KALAY
Sorumlu Yazar

Emrah Çelik

celikemrah822@gmail.com @

Önerilen Atıf:

Çelik, E., Durmuş, A. ve Türkoğlu, M. (2021). Iğdır İli ve Yakın Çevresinin Ornito-Turizm Perspektifinde Değerlendirilmesi, Journal of Academic Tourism Studies, 2(1): 32-44. 


\section{GİRIŞ}

Turizm genel tanımı itibariyle bir yerin tarihini, kültürünü ve doğal güzelliklerini görmek, tanımak, dinlenmek ve eğlenmek için yapılan faaliyetlerin bütünüdür (Özdemir, 1991). İnsanlar, yoğun iş temposundan ve günlük olağan faaliyetlerinden uzaklaşmak için devamlı yaşadıkları yerlerin dışına seyahatler düzenlerler (Seyidoğlu, 1992). Günümüzdeki turistlerin bir kesimi her ne kadar deniz-kum-güneş üçlemesine rağbet gösterse de bir başka kesimi de doğal ve kültürel güzelliklerin olduğu alanlara yönelerek hem hobilerini hem de özel ilgi alanlarını geliştirmeye ihtiyaç duymaktadır. Doğal alanlar, yaban hayatı bileşenleri, bitki örtüsü, iklim özellikleri ve manzara güzelliği ile turistik cazibeye sahip alanlardır (Çanga ve Üzümcü, 2020).

Türkiye sahip olduğu sahilleri, kadim medeniyetlere ev sahipliği yapması, farklı iklimi, doğa güzellikleri ve zengin flora ve fauna yapısına sahip olması gibi özellikleri ile turizm alanında önemli bir paya sahiptir. Ülkemizdeki kıyı sahillerinin fazlalığı insanlarda deniz-kum-güneş üçlüsünü akla getirse de sahil şeridi bulunmayan bölgelerde de doğa turizmi ön plana çıkmaktadır.

Doğa turizminin önemli kollarından biri olan ornito turizm (kuş gözlemciliği), doğasever birçok katılımcının kolay ve ucuz maliyetli bir şekilde vakit geçirmesine ve doğa bilincinin gelişmesine önemli katkılar sağlayan bir etkinlik olarak göze çarpmaktadır. Kuş gözlem turizmi, ekoturizmin en hızlı büyüyen segmentlerinden biri olarak kabul edilir (Biggs, 2013). Kuş gözlemciliği popüler bir eğlence aktivitesi olduğu için birçok gönüllü kuş gözlemcisi bu alanda değerli verilere katkıda bulunabilmektedir (Frątczakvd., 2020; Randlervd., 2021). Dünya çapında yaklaşık 80 milyon gönüllü kuş gözlemcisinin, 70 milyonu ABD'de, 15 milyonu İngiltere'de, 61 bininin Hollanda da ve yaklaşı 15 bininin de Brezilya'da olduğu bilinmektedir (Pivatto ve Sabino, 2005). Kuş gözlemciliği 20. yüzyılın başlarında ilk olarak İngiltere ve Amerika' da yaygınlaşın bir aktivitedir (Moss, 2009). Bu konu ile alakalı SCOPUS veri tabanında 'Birding-Ornithotourism' veya 'Birdwatcher-Ornithotourism' anahtar kelimeleri tarandığında yaklaşık 400'e yakın çalışma karşımıza çıkmaktadır. Yapılan çalışmaların türlerine yönelik içerik analizi yapıldığında büyük bir kısmının araştırma makalesi olduğunu takiben konferans bildirisi, derleme, kitap ve kitap bölümlerinden oluştuğu belirlenmiştir. Konu ile alakalı en fazla bilimsel çalışma yapan ülkelere ait görsel analiz Şekil 1'de gösterilmiştir. Buna göre ABD ve İngiltere ilk iki sırada yer almaktadır.

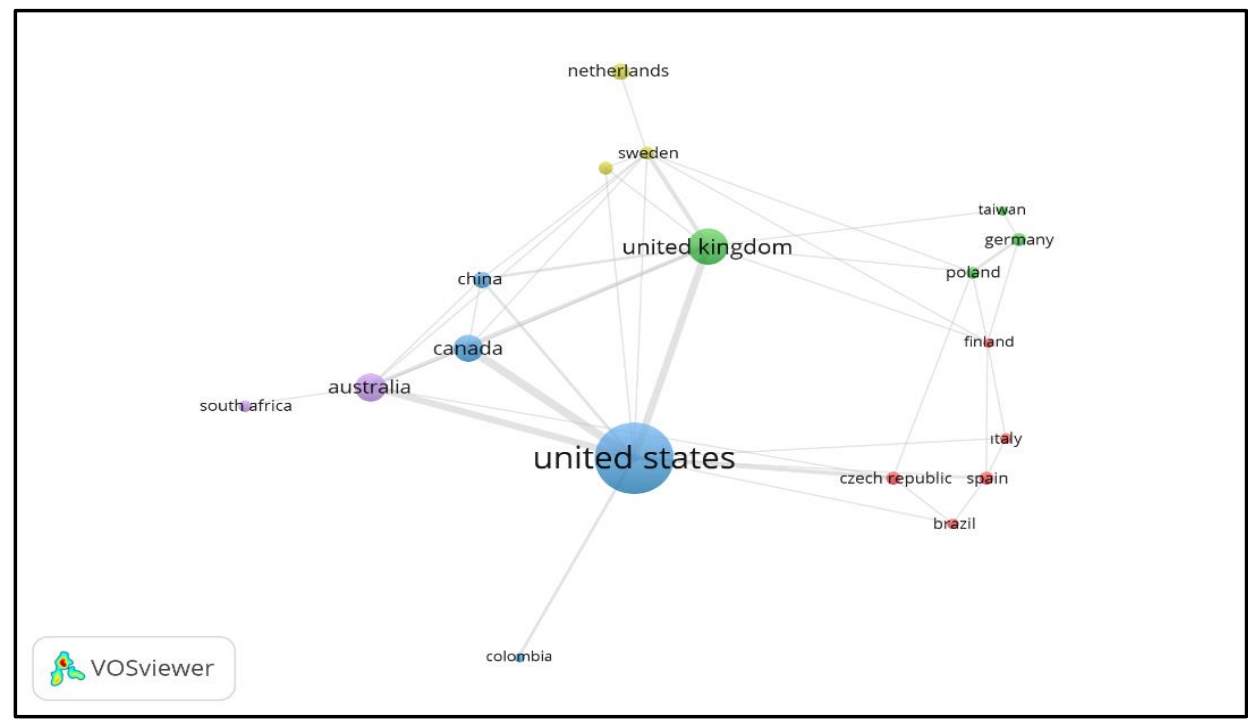

Şekil 1. Ülkelerin kuş gözlemciliği üzerine yaptıkları çalışmalara yönelik bir görsel analiz

Türkiye, kuş çeşitliliği açısından hemen hemen Avrupa kıtası ile eşdeğer bir zenginliğe sahiptir (Türkoğlu ve Şekercioğlu, 2018). Aynı zamanda coğrafi konumu itibariyle kıtalar arasında 
her yıl döngüsel olarak gerçekleşen kuzey-güney ve doğu-batı ana yönlü göç hareketlerinin üzerinde yer almaktadır.

Batı Palaearktik Bölgede yer alan dört önemli kuş göç yollarından iki tanesi ülkemiz semalarından geçmektedir (Şekil 2).

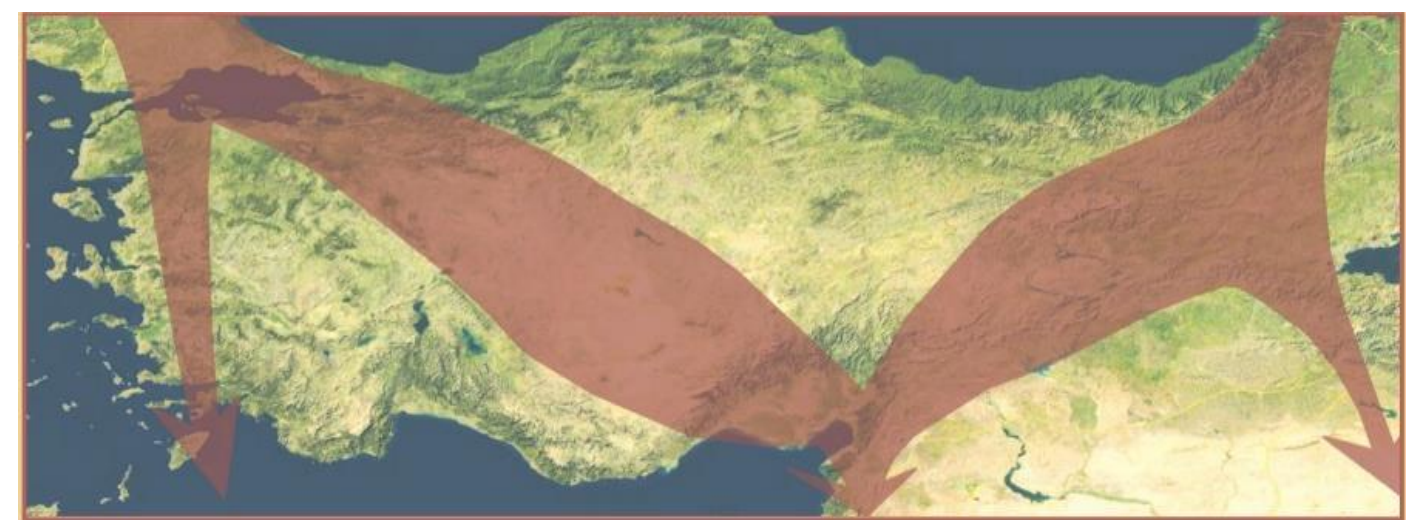

Şekil 2. Türkiye kuş göç yolları (Kuş Araştırmaları Derneği, 2013)

Türkiye sulak alanlar bakımından Ortadoğu ve Avrupa'nın en zengin ülkesi olup; bünyesinde yaklaşı 1 milyon hektarı aşan 250 civarında sulak alanı barındırmaktadır. Tarım ve Orman Bakanlığı'nca yapılan değerlendirmeler neticesinde bu alanlardan 86 tanesinin uluslararası öneme sahip olduğu belirtilmiştir (DKMP, 2021).

Bu özelliği sayesinde, ülkemiz sınırları içerisinde yer alan karasal ve sucul habitatlar, göçmen ve yerli kuşlar için neredeyse yılın her ayında farklı bölgelerde konaklama, üreme ve beslenme imkanları sunmaktadır. Bu durum ülkemizin kuş çeşitliliği ve gözlemciliği açısından ne kadar önemli olduğunu göstermektedir. Birçok yerli araştırmacı, ülkemizin farklı bölgelerinde yer alan sulak ya da doğal alanların biyoturizm ve ornitoturizm potansiyellerini ortaya koymuş ve bölgeye sağladıkları kültürel ve ekonomik faydalardan bahsetmişlerdir (Adızel vd., 2010; Adızel vd., 2011; Duran, 2012; Sevindi, 2013; Dönmez vd., 2016; Şahin ve Kahraman, 2017; Asan ve Yalçın, 2018; Durmuş, 2018a, b; Sevindi ve Kaya, 2019; Seven, 2020; Adızel vd., 2021).

\subsection{Kuş Gözlem (Ornito) Turizmi}

Kuşlar doğada indikatör (gösterge) canlı olarak görev yapmaktadırlar. Bir habitatta ya da ekosistemde bulunan kuş çeşitliliği, orada sağlıklı ve sürdürülebilir bir biyoçeşitliliğin döngüsüne işaret eder (Kiziroğlu, 2001). Bu canlı grubu gerek bilimsel çalışmalar gerekse hobiye dayalı rekreatif aktiviteler için geçmişten günümüze kadar düzenli olarak izlenmişlerdir (Arslan ve Kendir. 2019) Kuşların doğal çevrelerinde izlenmesi olarak adlandırılan ornito turizm, yerel bölgenin doğal çevre ve kültür değerlerini korumaya, topluluk geliştirmeye ve dikkate değer ekonomik faydalar sağlamaya yardımcı olan, sorumluluk sahibi ve eğitici bir doğa turizmidir (Son ve ark. 2011). Kuş gözlemcileri, doğa ile temasa geçerek, günlük yaşamın stresinden kaçmayı, doğal ve vahşi yaşam manzaralarının keyfini çıkarmayı umarlar (Connell, 2009; Nyaupane ve ark 2004; Sinha, 2001).

$\mathrm{Bu}$ faaliyet, insanlar ile kuşlar arasında oldukça yakın karşılaşmalara olanak sağlamaktadır (Goodfellow, 2017; Şekercioğlu, 2002) (Fotoğraf 1). 

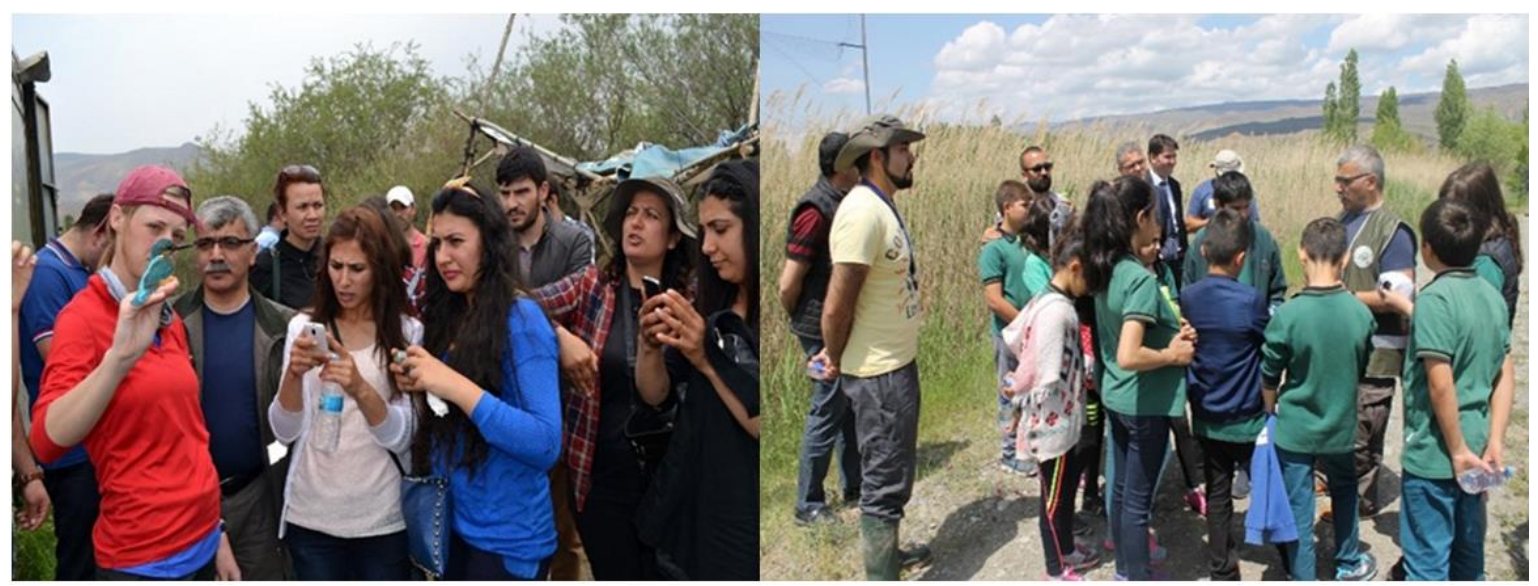

Fotoğraf 1. Kuş gözlem etkinliği ve doğa eğitimlerine ait görüntüler (Foto: Berkan Demir)

Kuş gözlemcileri, kuşlara yaklaşırken genellikle mümkün olduğunca göze çarpmadan gizlenirler, hareketleri ise diğer doğal alan kullanıcılarının hareketlerinden farklıdır (Radkovic et al., 2019). Hâkim varsayım, kuşlara yakın yaklaşımları mümkün kılmak için genellikle gizlilik ve sessizlik temel prensiplerdendir (Şekercioğlu, 2002). Kuş gözlemciliğine başlamak için çok az ekipman ve katılmak için minimum düzeyde fiziksel yetenek gerekmektedir. Kuşları izlemek için çeşitli optik aletler (fotoğraf makinesi, teleskop, dürbün......vs) ve türler hakkında elde edilecek bilgilerin kaydedilebileceği bir not defteri gerekmektedir.

\section{MATERYAL VE METOT}

Çalışmanın ana materyalini Iğdır ili'nde yapılmış avifaunistik çalışmalara ait yazılı kaynaklar, kitap, makale, rapor, belge, tezler, alanda yapılan gözlemlerle edinilen izlenimler ve bu esnada çekilen fotoğraflar oluşturmaktadır. Iğdır ili kuş gözlem turizmi potansiyelinin ortaya çıkarılmasında iki tip veri modelinden faydalanılmıştır. İlk olarak literatür taraması yapılarak bölge ile alakalı yapılmış çalışmalara ulaşılmıştır. İkinci olarak aktif saha çalışmaları neticesinde elde edilen veriler kullanılmıştır (Fotoğraf 2).

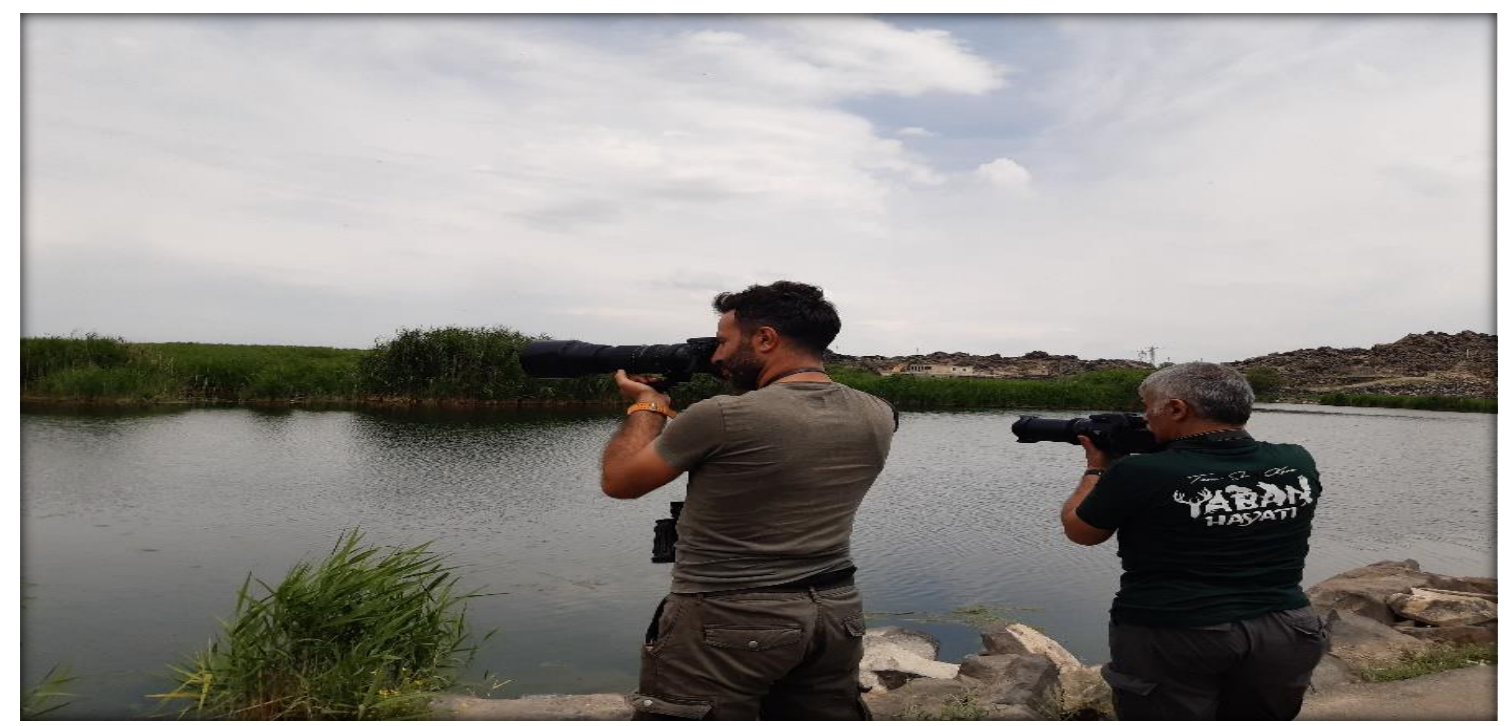

Fotoğraf 2. Aktif saha çalışmasından bir görüntü (Gözlemciler: Emrah Çelik, Mete Türkoğlu)

\subsection{Iğdır İli Coğrafi Özellikleri}

Iğdır İli, Doğu Anadolu Bölgesinin Erzurum-Kars bölümünde Sürmeli çukuru adı verilen Ağrı Dağı eteklerinde yer almaktadır. İlin kuzey ve kuzeydoğusunda Ermenistan, doğusunda Nahçıvan 
ve İran, güneyinde Ağrı, batı ve kuzeybatıdan ise Kars ile sınır komşusudur (Harita 1). Iğdır üç ülkeye sınır teşkil etmesi sebebiyle ticaret ve seyahat anlamında çok işlek bir ulaşım ağına sahiptir. İlin sınır komşusu olan Kars (Ani harabeleri) ve Ağrı (Doğubayazıt- İshakpaşa Sarayı) illerinde yer alan turistik yerlere ulaşım Iğdır İli üzerinden sağlanmaktadır (Şimşek ve Alim, 2009).

Iğdır'a gelen yerli ve yabancı turistlere yetecek kadar konaklama tesisleri vardır. $\mathrm{Bu}$ konaklama tesislerinin turizm bakanlığı belgeli olanları iki adet 3 yıldızlı ve belediye belgeli konaklama statüsüne sahip altı adet otel bulunmaktadır (Kültür ve Turizm Bakanlığ1, 2021).

Kültür ve Turizm Bakanlığı'nın verilerine göre Iğdır 'a son beş yılda gelen ortalama turist sayısı Tablo 1 üzerinde gösterilmiştir.

Tablo 1. Iğdır'a gelen turistler ile ilgili açıklayıcı bilgiler (2016-2020)

\begin{tabular}{|c|c|c|c|c|c|c|c|c|c|c|c|c|}
\hline \multicolumn{4}{|c|}{ Ziyaret Eden } & \multicolumn{4}{c|}{ Geceleme } & \multicolumn{3}{c|}{ Ortalama kalıs süresi } & \multicolumn{3}{c|}{ Doluluk oranı (\%) } \\
\hline Y11 & Yabanc1 & Yerli & Toplam & Yabanc1 & Yerli & Toplam & Yabanc1 & Yerli & Toplam & Yabanc1 & Yerli & Toplam \\
\hline $\mathbf{2 0 1 6}$ & 5409 & 24178 & 29587 & 6647 & 29532 & 36179 & 1,2 & 1,2 & 1,2 & 6,73 & 29,88 & 36,61 \\
\hline $\mathbf{2 0 1 7}$ & 12.099 & 18.926 & 31.025 & 15199 & 26649 & 41848 & 1,25 & 1,4 & 1,34 & 12,8 & 22,43 & 35,22 \\
\hline $\mathbf{2 0 1 8}$ & 4269 & 16799 & 21068 & 4779 & 21927 & 26706 & 1,12 & 1,31 & 1,27 & 4,92 & 22,56 & 27,48 \\
\hline $\mathbf{2 0 1 9}$ & 2902 & 16604 & 19506 & 4296 & 24132 & 28428 & 1,48 & 1,45 & 1,46 & 4,42 & 24,83 & 29,25 \\
\hline $\mathbf{2 0 2 0}$ & 521 & 12607 & 13128 & 667 & 19294 & 19961 & 1,28 & 1,53 & 1,52 & 0,69 & 19,85 & 20,54 \\
\hline
\end{tabular}

Kaynak: Kültür ve Turizm Bakanlığı, www.kulturturizm.gov.tr, Erişim: 15.05.2021

Iğdır'a ulaşım havayolu ve karayolu vasıtasıyla sağlanmaktadır. Karayolu vasıtasıyla başta İstanbul ve Ankara, olmak üzere birçok büyükşehirlerden Iğdır'a düzenli otobüs seferleri yapılmaktadır. Kars yolu üzerinde şehir merkezine $18 \mathrm{~km}$ mesafede bir havaalanı bulunmaktadır. Havaalanı 2013 yılında faaliyetine başlamış ve halen aktif olarak çalışmaktadır. Ankara ve İstanbul'a karşılıklı seferler yapılmaktadır.

Iğdır Havalimanının Ağrı Dağı, İshak Paşa Sarayı, Nuh'un Gemisi, dünyanın en büyük ikinci meteor çukuru gibi turizm bölgelerini içinde barındıran Doğubayazıt'a yakınlığ 1 (yaklaşık $70 \mathrm{~km}$ ) nedeniyle yerli ve yabancı turistler tarafından da yoğun olarak kullanılmaktadır (Tutar vd., 2013).

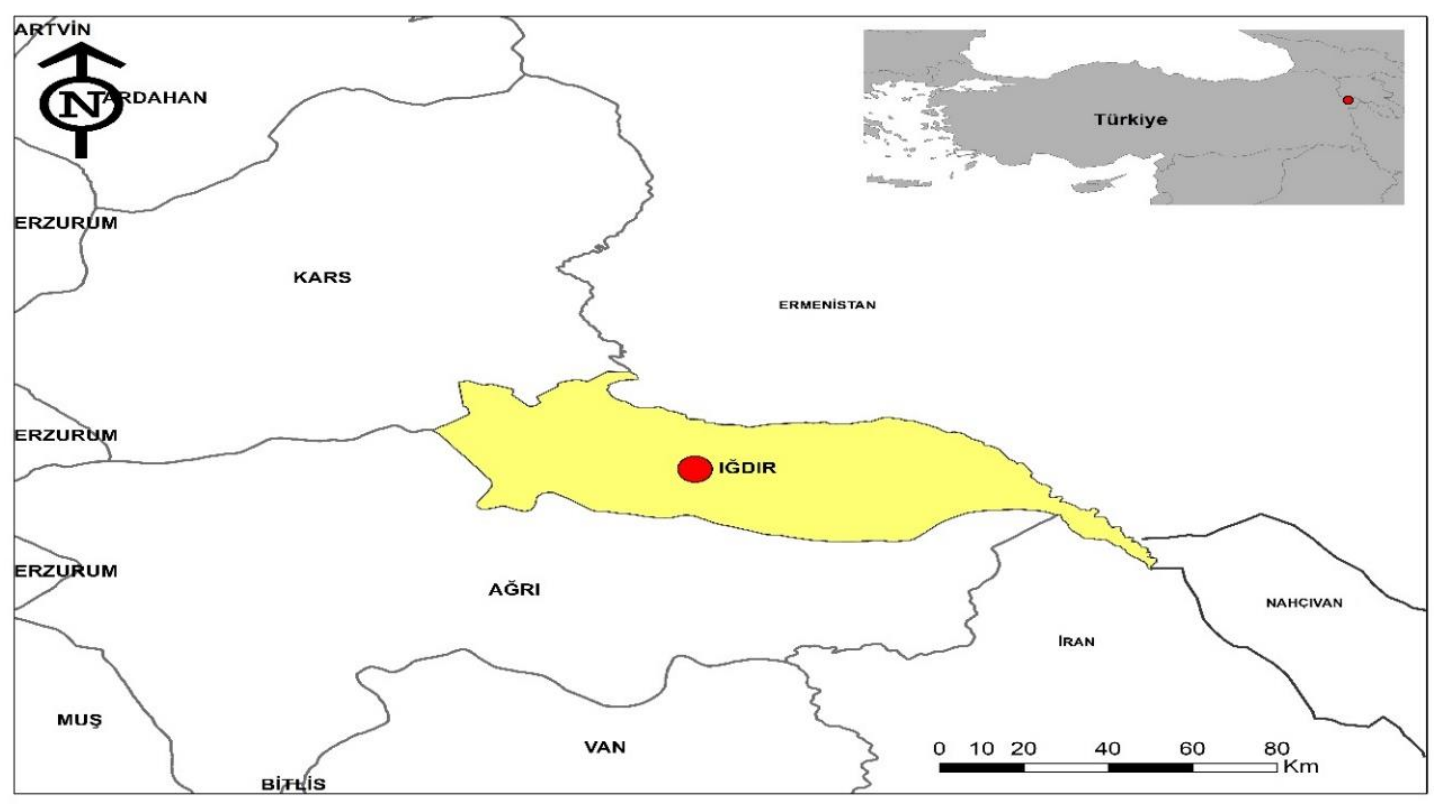

Harita 1. Iğdır İli'nin coğrafi konumu 


\section{BULGULAR ve TARTIŞMA}

\subsection{Iğdır İli'nin Ornito Turizm Potansiyeline Sahip Alanları ve Kuş Çeşitliliği}

Ülkemiz sahip olduğu kuş çeşitliliğiyle kuş gözlemciliğinin yaygınlaşmasına zemin hazırlarken, çoğu kuş türünün yaşamsal faaliyetlerini sürdürdügü sulak alanları daha kıymetli hale getirmektedir (Sevindi, 2013). Yarar ve Magnin (1997), Önemli Kuş Alanları araştırmasında ülkemiz sınırları içerisinde ulusal ve uluslararası öneme sahip 184 ÖKA olduğunu rapor etmişlerdir. Bu çalışmayla birlikte Türkiye' nin koruma statüsünden yoksun birçok önemli kuş alanının tanıtılması hiz kazanmıştır.

Iğdır İli; Afrika-Avrasya kuş göç yolları üzerinde bulunmaktadır. Uluslararası kriterlere göre belirlenmiş dört Önemli Doğa Alanı (ÖDA) ve iki Önemli Kuş Alanı'nın (ÖKA) sınırlarının bir kısmı veya tamamı il sınırlarında yer almaktadır. Bunlar Aras Vadisi (Kars-Iğdır; ÖDA), Iğdır Ovası (Iğdır; ÖDA, ÖKA), Ağrı Dağı (Ağrı- Iğdır; ÖDA, ÖKA), Balık Gölü'dür (Ağrı-Iğdır; ÖDA, ÖKA). Bu alanlara ek olarak bölgedeki önemli kuş potansiyeline sahip alanlarda bulunmaktadır. Bunlar; Bulakbaşı sulak alanı, Aras-Karasu Taşkınları ve Aras Vadisidir (Harita 2).

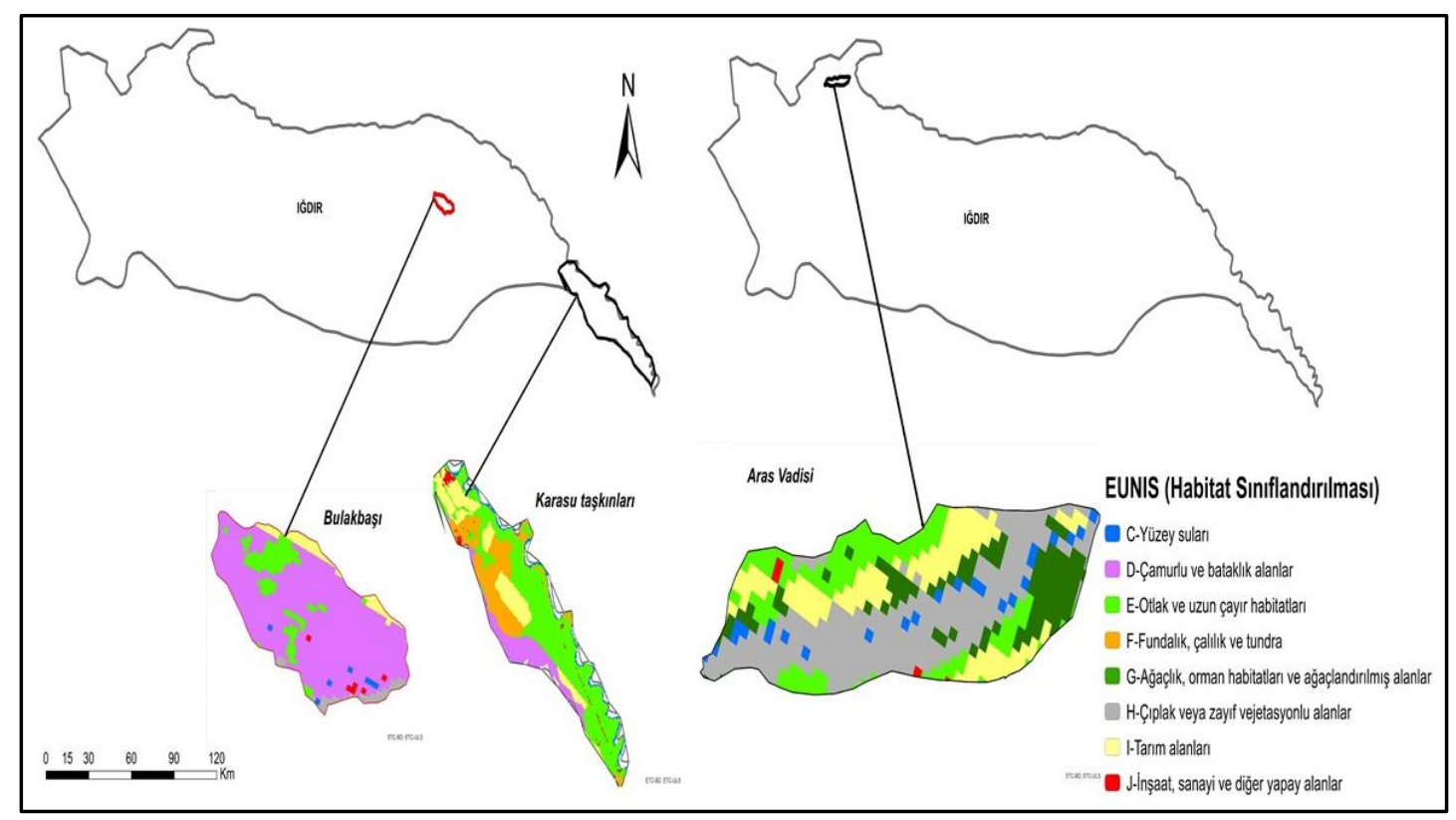

Harita 2. Iğdır İl'inde önemli kuş potansiyeline sahip alanlar ve habitat yapıları (EUNIS, 2018)

\subsection{Aras Vadisi Kuş Cenneti}

Bölgedeki önemli bir sulak alan ekosistemi olan Aras Nehri; sazlık, bataklık, çayırlık ve çalılık habitat yapısı ile kuşlara önemli bir yaşam alanı sunmaktadır (Fotoğraf 3). Göç dönemleri olan ilkbahar ve sonbaharda farklı ötücü ve yırtıcı kuş türlerinden binlercesi Aras Vadisi koridorundan göç ederek ilkbaharda üreme bölgeleri olan 1lıman kuzey ülkelerine, her sonbaharda ise kışlama bölgeleri olan sıcak Afrika ülkelerine göç etmektedir. Bu göç esnasında on binlercesi bu vadide konaklamakta, beslenmekte ve yollarına devam etmektedir. 


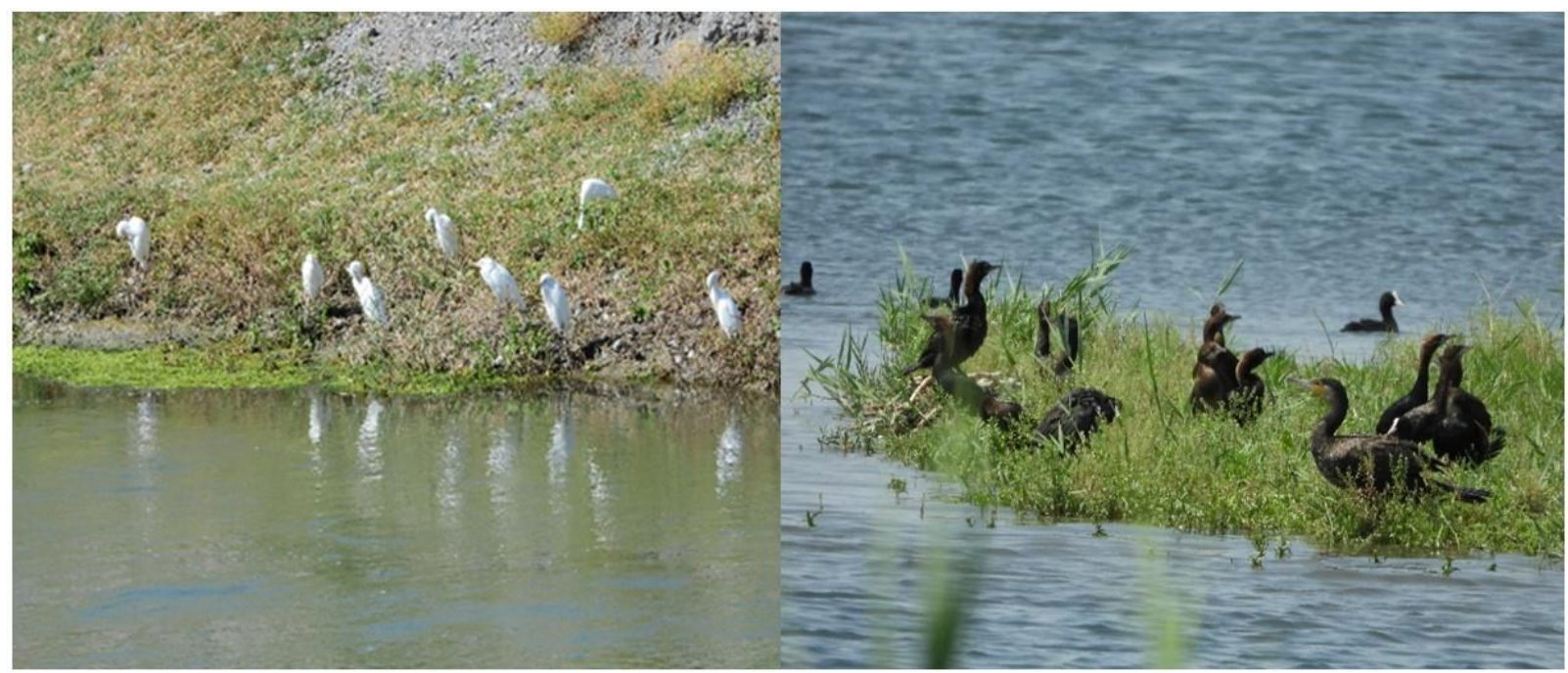

Fotoğraf 3. Aras Vadisi Kuş Cenneti (soldaki: Büyük akbalıkçıl (Ardea alba), sağdaki:Karabatak (Phalacrocorax carbo) Foto: Mete Türkoğlu)

Aras Vadisi kuş cenneti etrafı kurak bozkırla çevrili bir alanda vaha niteliği taşımaktadır. Bu özelliği kuşların sadece göç mevsiminde değil, soğuk kış aylarında da kuşlar açısından doğal bir sığınak teşkil etmektedir.

\subsection{Aras-Karasu Taşkınları}

Aras Karasu Taşkınları Sulak Alanı, idari olarak Iğdır ili Aralık ilçesi sınırlarında yer almakta olup, Iğdır şehir merkezine kuş uçuşu 67 km uzaklıktadır. Alan, Aralık ilçesinin güneydoğusunda, ülkemizin İran, Nahçıvan ve Ermenistan sınırında yer almaktadır (Fotoğraf 4).

Alanın toplam yüzölçümü 9090 ha olup rakımı 813 metredir. Kuzeyden güneye Tuzluca bozkırlarından başlayıp Aras Nehri taşkınlarını kapsayacak şekilde batıya ilerleyerek Iğdır Ovası' nın bir kısmını ve Dil Ovası'nı içine almaktadır. Alan sahip olduğu farklı habitat tipleri (sazlık, ıslak çayırlık, bataklık, ...vb) ile birçok yaban canlısına özellikle de kuşlara ev sahipliği yapmaktadır. Özellikle ilkbahar dönemine girilmesiyle birlikte eriyen karlar ve mevsimsel yağışlarla beraber verimli habitatlar oluşmaktadır. Aynı zamanda bölgenin tuzcul step özellikte olması benzersiz bir tuzcul bitki kompozisyonun oluşmasına imkân tanımaktadır.

Alanın Türkiye'nin çatısı olarak adlandırılan Ağrı Dağı'na nazır olması rekreasyon açısından büyük önem arz etmektedir.

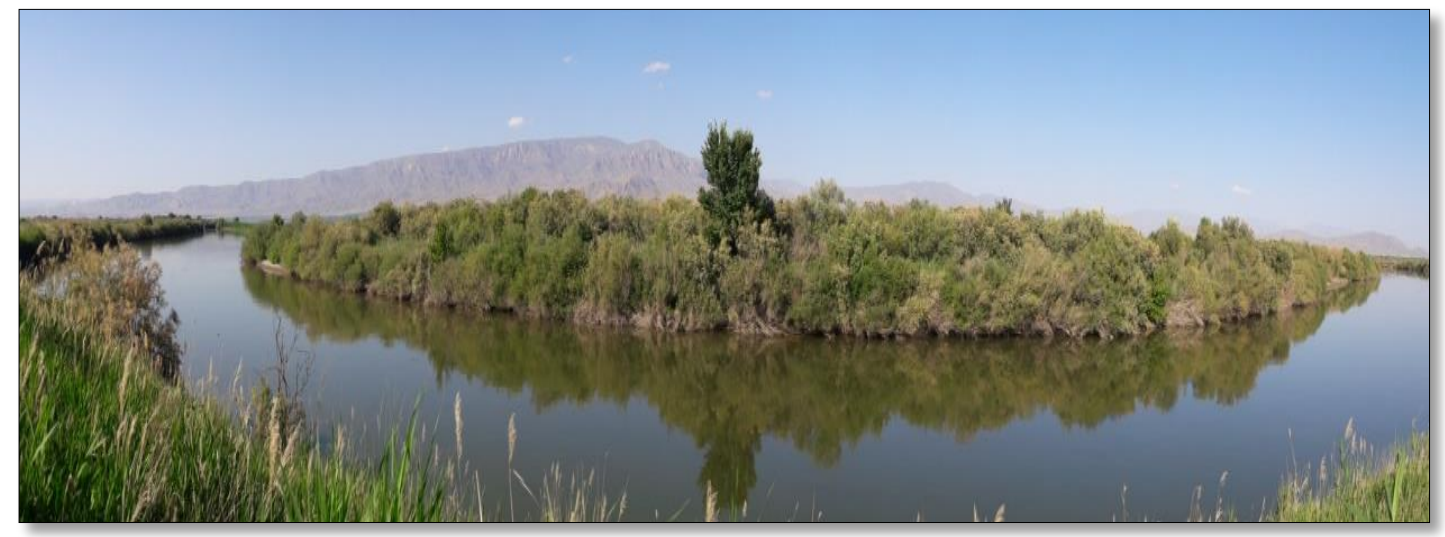

Fotoğraf 4. Aras-Karasu Taşkınlarına ait bir görüntü (Foto: Atilla Durmuş) 


\subsection{Bulakbaşı Sulak Alanı}

Bulakbaşı Sulak Alanı, Iğdır şehir merkezine 40 kilometre uzaklıktaki mesafede, Ağrı Dağı'nın buzul suları ile beslenen bir sulak alandır (Fotoğraf 5). Bulakbaşı Sulak alanı çevresinde herhangi bir kirletici etmenin olmaması ve temiz yer altı suları beslenmesinden ötürü her daim doğal bir görünüm sergilemektedirler.Birçok kuş türü ve yabani hayvanı barındıran Karasu havzasındaki Bulakbaşı sulak alanı, rekreasyon ve doğa amaçlı yapılan faaliyetlerde önemli bir yer tutmaktadır.

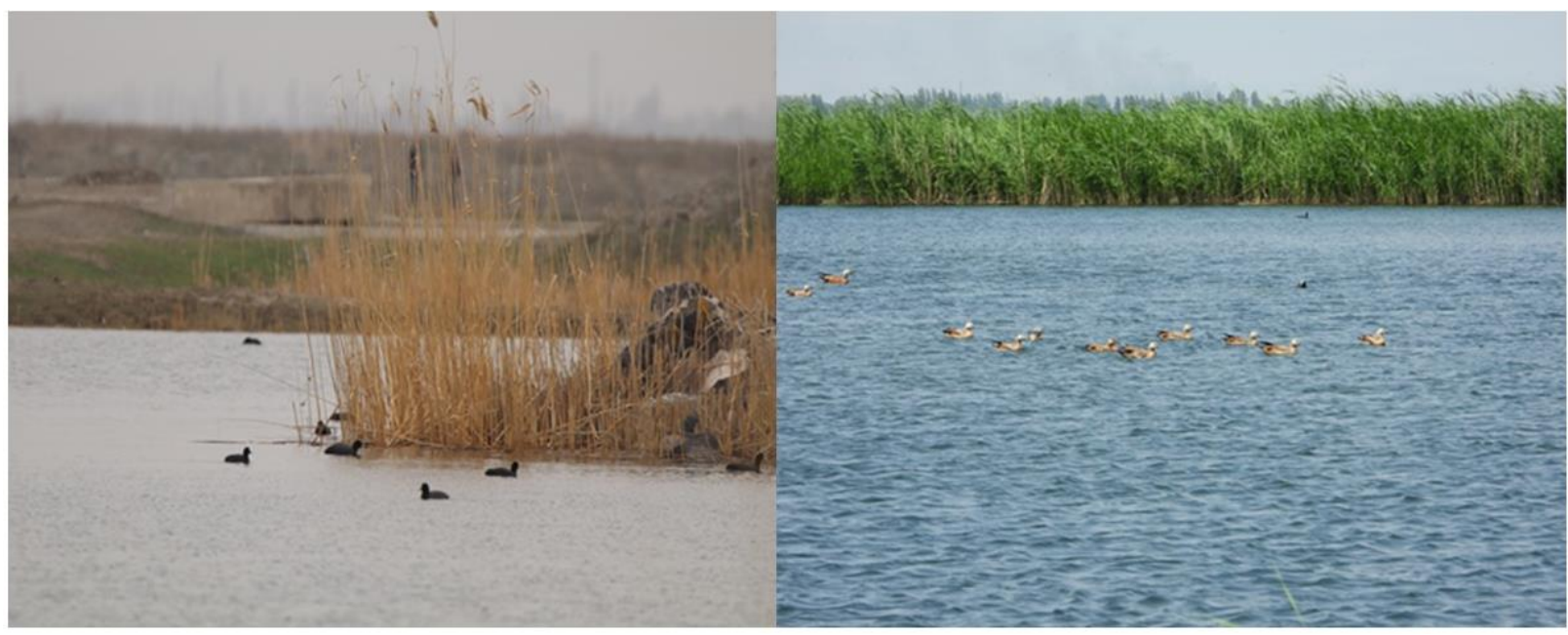

Fotoğraf 5. Bulakbaşı sulak alanına ait görüntüler (soldaki: Sakarmeke (Fulica atra), sağdaki:Angıt (Tadorna ferruginea) (Foto: Emrah Çelik)

Türkiye' de gerçekleştirilen avifauna çalışmaları ve gözlemlerle birlikte bugüne dek 489 türün kaydı verilmiştir (Trakuş, 2021). Beaman ve Madge, (2010) adlı araştırmacılar Türkiye' nin de içinde yer aldığı Batı Palaearktik Bölge' de ise yaklaşık 900 türün kaydını vermişlerdir.

Türkiye'nin en doğusunda yer alan ve üç ülkeye sınır teşkil eden Iğdır İli Kafkaslar biyoçeşitlilik sıcak noktası üzerinde bulunmaktadır. Kuş göç yolları üzerinde yer alan Iğdır aynı zamanda ülkemizin en büyük milli parkı olan Ağrı Dağı Milli Parkının sınırlarının büyük bir kısmını da bünyesinde barındırmaktadır.

Iğdır İli’nde daha önce yapılmış avifauna çalışmaları incelendiğinde bölgede birçok yerli ve yabancı araştırmacının kuş kayıtlarının olduğu görülmüştür (Balmer ve Betton, 2007, 2008; Balmer ve Murdoch, 2009; DKMP, 2018; Eames, 1991; Eken vd., 2006; Kılıç ve Eken, 2004; Kirwan, 1992; Martins, 1989; Yarar ve Magnin, 1993). Bölge ile ilgili yapılmış en güncel avifauna çalışmaları, Tarım ve Orman Bakanlığı' nca 2018 yılında yürütülen 'Iğdır İli’ nin Karasal ve İç Su Ekosistemleri Biyolojik Çeşitlilik Envanter ve İzleme İşi' projesi ile Iğdır'ın Kuşları (Türkoğlu ve Şekercioğlu, 2018) adlı çalışmalardır. Çalışmalar detaylı olarak incelendiğinde bölgede yapılmış olan biyolojik çeşitlilik çalışmasında 194, yayımlanan 'Iğdır'ın Kuşları' adlı eserde ise 330 kuş türünün olduğu bildirilmiştir. Bu iki detaylı çalışma arasındaki tür sayı farklılıkları araştırmaların kapsadığı zaman aralıklarından kaynaklandığı düşünülmektedir.

Aynı zamanda bölgede 2006 yılından beri faaliyet gösteren Aras Kuş Halkalama İstasyonunda da şimdiye kadar 199 farklı kuş türünün halkalandığı rapor edilmiştir (DKMP Genel Müdürlüğü, 2020). Halkalanan kuş türleri içerisinden Acrocephalus griseldis (Basra kamışçını) Türkiye için yeni kayıt olarak literatüre eklenmiştir (Neate-Cleggvd., 2019). Bunun yanında Türkiye' de ender görülen Phylloscopus sindianus (Kafkas çıvgını), Merops persicus (Yeşil arıkuşu) ve Porphyrio porphyrio (Saz horozu)bölgede kaydı verilen türlerdendir. Özkoç (2020), ülkemizde Güneydoğu ve Doğu Anadolu Bölgesi'nde az sayıda alanda ürediği bilinen Merops persicus (Yeşil arıkuşu)' un (Kirwan ve ark 2008; Boyla ve ark 2019) Aras Vadisi'nde üremesinin kuvvetle olası olduğunu belirtmiştir. Türkoğlu ve Şekercioğlu (2018), türün bölgeye nisan ayı ortalarında geldiğini ekim ayı sonlarına doğru da 
bölgeden ayrıldıklarını belirtmişlerdir. IUCN (2021) verilerine göre Meropspersicus (Yeşil arıkuşu) türünün ülkemiz sınırları içerisinde sadece Şanlıurfa ve Iğdır illerinde yerleşik bir tür olduğuna dairdir (Şekil 5).Ülkemizde Çukurova, Kızılırmak ve Göksu deltalarında üreme kaydı verilen Porphyrio porphyrio (Saz Horozu)'nun Iğdır Tuzluca Yukarı Çıyrıklı Köyü'nün birinci göl mevkiinde tespit edilmiş ve türün bölgede üreyebileceği uygun alanların olduğu gözlenmiştir (Fotoğraf 6). Tür ile ilgili daha sonra detaylı çalışmalar yapılarak bölgedeki durumu tespit edilecektir.

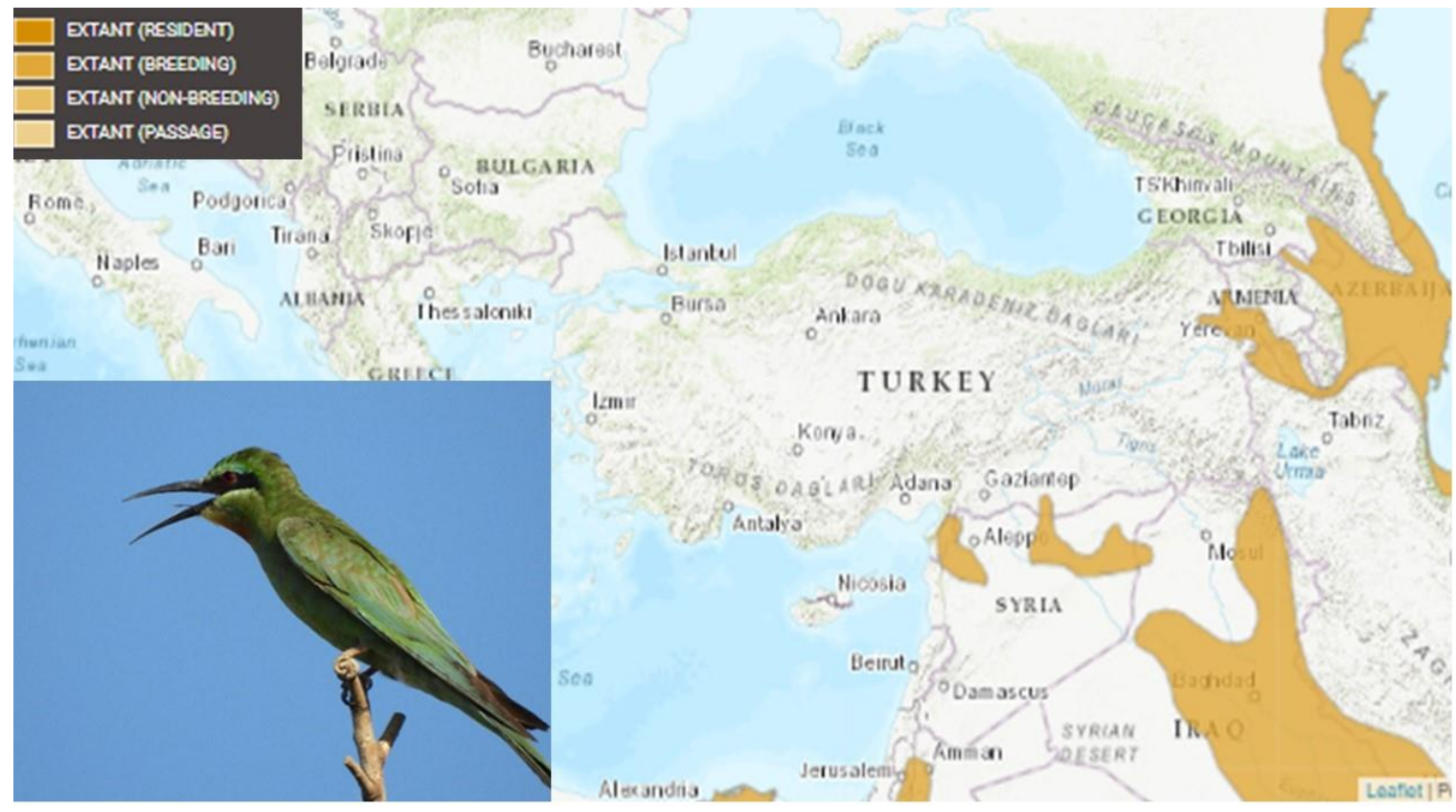

Şekil 5. Merops persicus (Yeşil arıkuşu)'un ülkemizdeki yayılış alanları (IUCN, 2021 Erişim tarihi: 08.05.2021, Foto: Mete Türkoğlu)

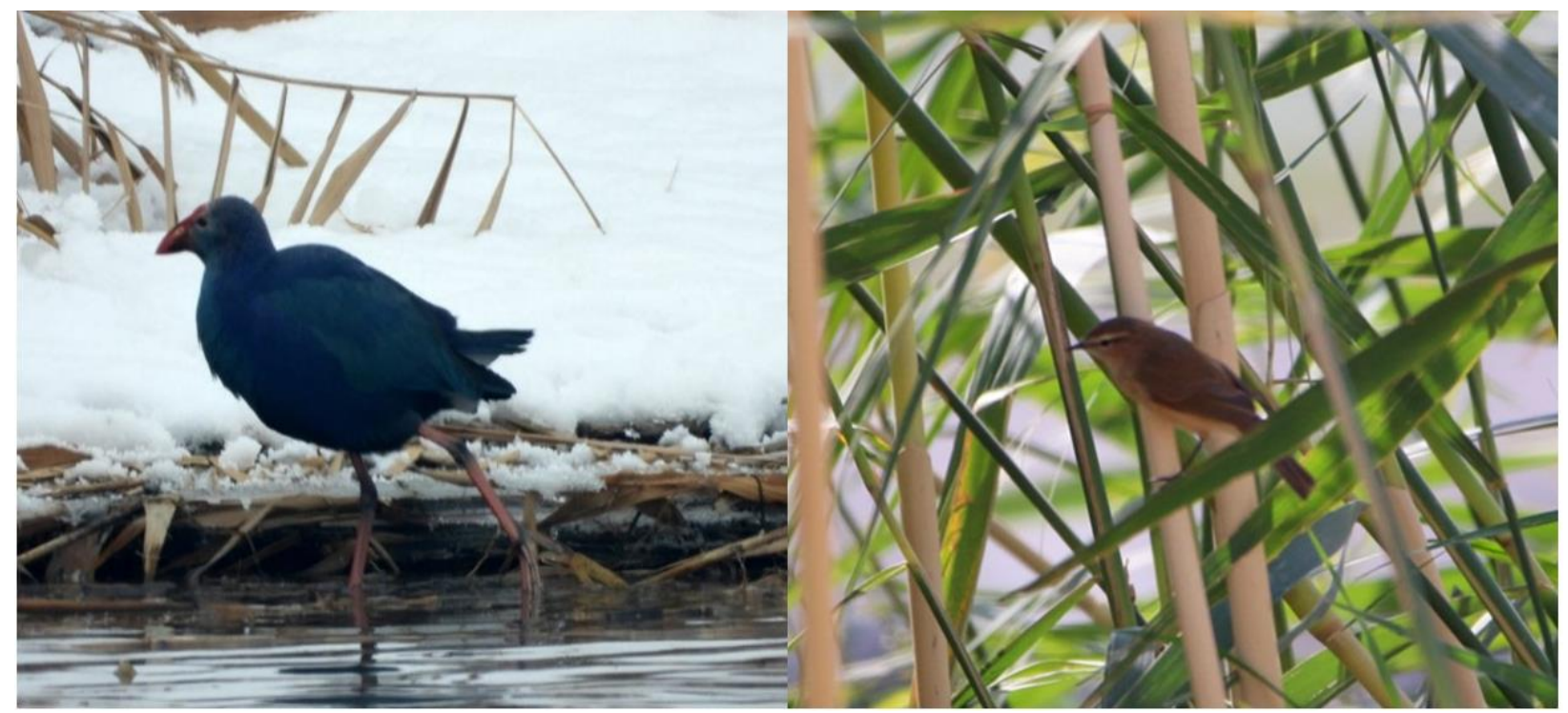

Fotoğraf 6. Aras Vadisi'nde görülen önemli kuş türleri, (soldaki Porphyrio porphyrio (Saz Horozu), sağdaki Phylloscopus sindianus (Kafkas çıvgını))

Ülkemizde ender görülen bir diğer tür olan Sylvia mystacea (Pembegöğüslü ötleğen), en kuzeydeki üreme kayıtları Aras Vadisi'nden verilmiştir (Boyla ve ark 2019) (Fotoğraf 7). Türkoğlu ve Şekercioğlu (2018), türün Iğdır'a nisan ayı başlarında geldiğini eylül ayı sonlarında da bölgeden ayrıldığını bildirmişlerdir. Tür ile literatür araştırması yapıldığında, türün Güney Doğu Anadolu'da 
üreme kaydının olduğu (Karataş ve Üçeş, 2021) geçmiş yıllarda da Amik Gölü çevresinde de kayıtlarının olduğu bildirilmiştir (Atahan ve ark. 2008).Aras Vadisi için önemli bir tür olan ve nesli tehlike altında olan Neophron percnopterus (Küçük akbaba) bölge için yerleşik bir türdür (Fotoğraf 7). Türün Avrupa'daki en büyük üreyen popülasyonu İspanya ve Türkiye'de bulunmaktadır (Velevskivd., 2015). IUCN (2021)'in güncel verilerine göre türün Kuzey Avrupa ve Güney Afrika'nın bazı ülkelerinde soyunun tükendiği ya da tükenme riskiyle karşı karşıya olduğudur. Bu bilgiler ışığında türün ülkemizdeki popülasyon durumunun iyi olması ve Iğdır Aras Vadisi'nde de sıklıkla gözlemlenebiliyor olması hem kuş gözlemciliği açısından hem de tür için yapılacak olan koruma projeleri için oldukça önem arz etmektedir.

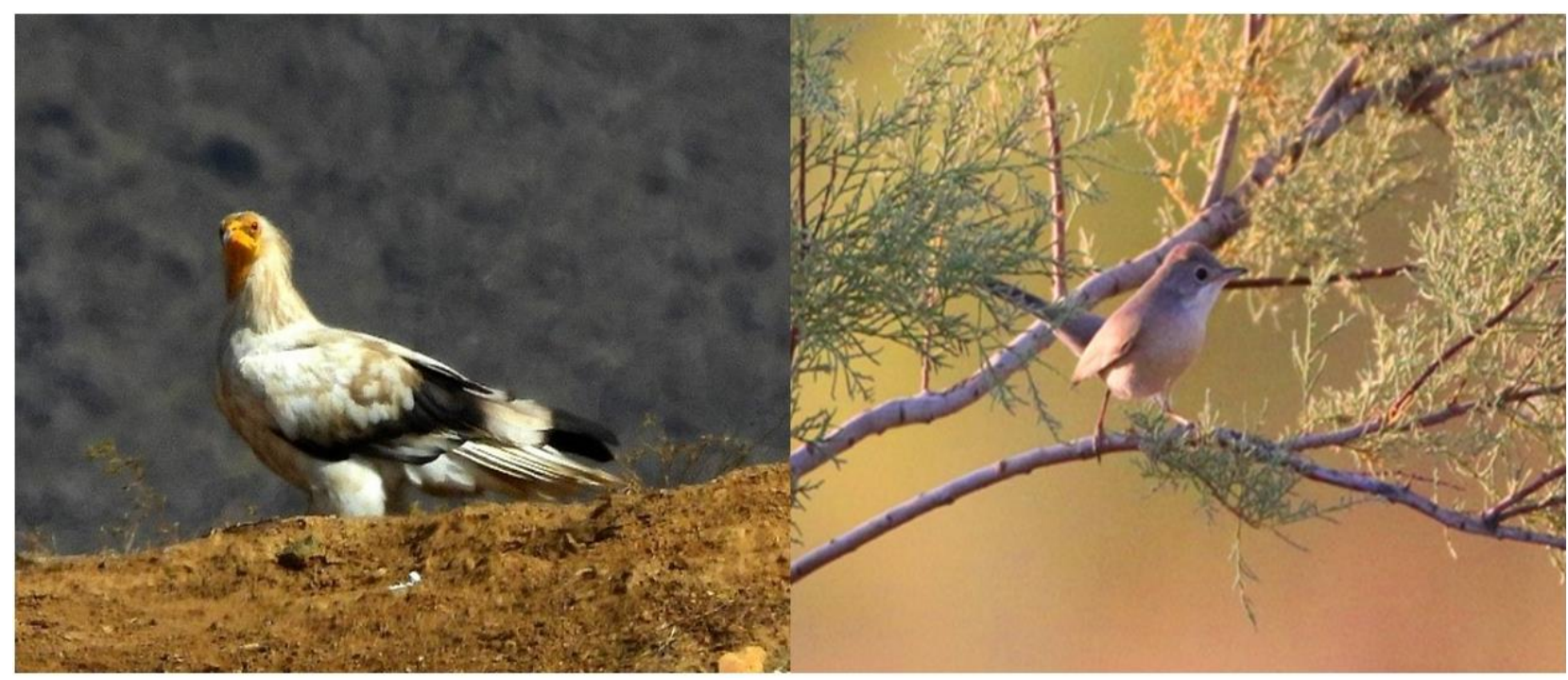

Fotoğraf 7. Bölgede tespit edilen önemli kuş türleri (soldaki Neophron percnopterus (Küçük akbaba), sağdaki Sylvia mystacea (Pembegöğüslü ötleğen))

Bölge için önemli olan bir diğer tür Poyraz kuşu (Haematopus ostralegus)dur. Aktif saha çalışmalarımızda türün vadi boyunca yayılış gösterdiği ve olası üreme alanlarının var olduğu belirlenmiştir. (Fotoğraf 8).

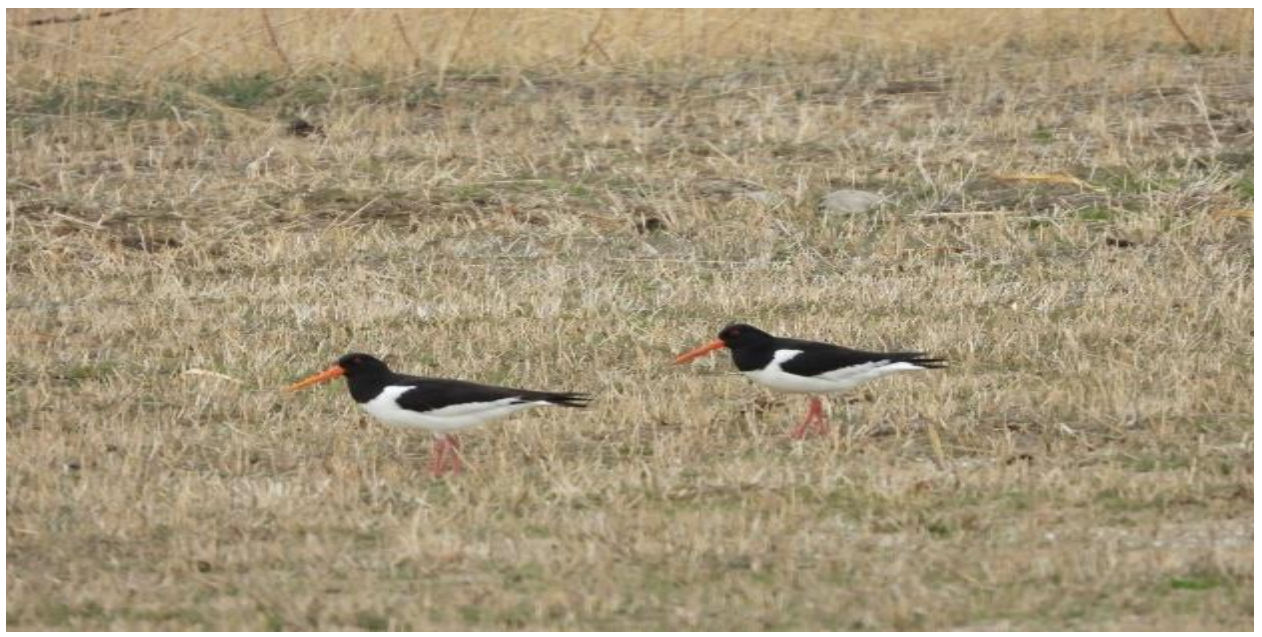

Fotoğraf 8. Haematopus ostralegus (Poyraz kuşu) (Foto: Mete TÜRKOĞLU) 


\section{SONUÇ}

Iğdır ili Doğu Anadolu Bölgesine seyahat eden kafile ve turların önemli bir kavşak noktası üzerinde bulunmaktadır. Iğdır'a büyük şehirlerden ve çevre illerden düzenli olarak otobüs seferleri düzenlenmektedir. Ayrıca 2013 yılında ilde havaalanının açılmasıyla birlikte her hafta düzenli olarak İstanbul ve Ankara'dan karşılıklı seferler yapılmaktadır. Konumu itibariyle Nahçivan ve İran'a sınır komşusu olması yabancı turistlerin bölgeyi sürekli ziyaret etmesine imkan tanımaktadır. Bu ülkelerden gelenlerin Türkiye' ye vizesiz girebilmeleri de geçişleri kolaylaştırmaktadır. Kültür ve Turizm Bakanlığı'nın uzun yıllara ait verilerine göre Iğdır çevre illere nazaran daha çok turist tarafından ziyaret edilmektedir. Iğdır, yerli ve yabancı turistlere sağladığı turizm faaliyetleri açısından da oldukça zengindir. Türkiye'nin en büyük milli parkı olan Ağrı Dağı Milli Parkının büyük bir kısmının il sınırları içerisinde yer alması ekoturizm ve biyoturizm açısından büyük önem arz etmektedir.

Bölge yaban hayatı ve doğa fotoğrafçılı̆̆ için oldukça önemli bir yerdedir. Konumu itibariyle Afrika-Avrasya kuş göç yolları üzerinde bulunan il, uluslararası öneme sahip alanları da bünyesinde barındırmaktadır. Kafkasya biyoçeşitlilik sıcak noktası üzerinde bulunan Iğdır'da bilimsel çalışmalarla birlikte 330 kuş türünün varlığı bildirilmiştir. Bu sayı Türkiye avifaunasının yaklaşık \%67'sine denk gelmektedir. Aynı zamanda Türkiye' de ender görülen ve kritik öneme sahip bazı türlerin kayıtları da Iğdır İli'nden verilmiştir. Zengin avifauna çeşitliliğine sahip Iğdır'da alternatif turizm olan ornito turizmin geliştirilmesi ve yeterince tanitılması, bölgeye sosyal ve ekonomik yönden olumlu katkılar sağlayacağı düşünülmektedir. Çalışma içerisinde belirtilen önemli kuş alanlarına ulaşım oldukça kolay ve günübirlik şekilde ziyaret etmeye uygundur. Şehir merkezinden özel araçla ortalama Aras-Karasu Taşkınları sulak alanına $45 \mathrm{dk}$, Bulakbaşı sulakalanına $30 \mathrm{dk}$ ve Aras Vadisi Kuş Cennetine 50-60 dk bir yolculukla ulaşılabilmektedir.

Sonuç olarak; Iğdır sahip olduğu önemli doğa ve kuş alanlarının yanında kritik öneme sahip kuş türlerini de barındırması, bölgenin kuş gözlemciliği ve doğa fotoğrafçılığı açısından önemini ortaya koymaktadir.

\section{Kaynakça}

Adızel, Ö., Durmuş, A., Azizoğlu, E., ve Çelik, E. (2021). Nature and Biotourism Potential of Ağrı Province. Igdir International Applied Sciences Congress. April 14-15, Igdir,Turkey.

Adızel, Ö., Durmuş, A., Kiziroğlu, İ., Avcı, F., Azizoğlu, E., Çelik, E., Tanrıverdi, A., veNergiz, H. (2011). Ornitofestival ve Ornitoturizim Etkinliklerinin Sulak Alan Korumasına Katkısınının “I. Doğunun Kanatları Erçek Gölü Flamingo Festivali - Van" Örneğinde İrdelenmesi. II. Türkiye Sulak Alanlar Kongresi, 22-24 Haziran,Kırşehir, Türkiye.

Adızel, Ö., Durmuş, A., ve Akın, G. (2010). Ağrı'nın Doğa Turizmi, Biyoturizm ve Ornitoturizm Potansiyeli. III. Uluslararası Ağrı Dağı ve Nuh'un Gemisi Sempozyumu, 12-14 Ekim, Ağrı, Türkiye.

Arslan, E., ve Kendir, H. (2019). Kış Turizmi Potansiyeli Açısından Muş İlinin SWOT Analizi ile Değerlendirilmesi. Anemon Muş Alparslan Üniversitesi Sosyal Bilimler Dergisi, 7(6), 167-173.

Asan, H., Yalçın, H. M., ve Şimşek, E. (2018). Sivas İli Kuş Gözlem Turizmi Potansiyelinin Değerlendirilmesi. Akademik Sosyal Araştırmalar Dergisi, 6(74), 630-655

Atahan, A., Gül, O., ve Atahan, M. (2008). Hatay Kuş Gözlem Raporu.

Balmer, D., ve Betton, K. (compilers) (2007). Around the Region. Sandgrouse, 29 (1), 9-16.

Balmer, D., ve Murdoch, D. (compilers) (2009). Around the Region. Sandgrouse,31 (1), 91-103.

Beaman, M., ve Madge, S. (2010). The Hand book of Bird Identification for Europe and the Western Palearctic. Christopher Helm Publishers, London.

Biggs, D. (2013). Birding, sustainability and ecotourism. International handbook on ecotourism.University of Queensland, School of Tourism, Australia 
Boyla, K.A., Sinav, L., ve Dizdaroğlu D.E. (2019). Türkiye Üreyen Kuş Atlası. WWF-Türkiye, Doğal Hayatı Koruma Vakfi. İstanbul.

Connell, J. (2009). Bird watching, twitching and tourism: towards an Australian perspective. Australian Geographer, 40(2), 203-217.

Çanga, A. Ç., ve Üzümcü, T. P. (2020). Sürdürülebilir Eko-Turizm Destinasyonları Olarak Sulak Alanlar: Uluabat Gölü.ÇOMÜ Ziraat Fakültesi Dergisi,8(2), 335-346.

DKMP, (2018). Iğdır İli'nin Karasal ve İç Su Ekosistemleri Biyolojik Çeşitlilik Envanter ve İzleme İşi Sonuç Raporu. T.C. Tarım ve Orman Bakanlığı Doğa Koruma ve Milli Parklar Genel Müdürlüğü 13. Bölge Müdürlüğü Iğdır Şube Müdürlüğü, Ankara, 453

Duran, C. (2012). Türkiye'de Dağlık Alanların Kırsal Turizm Açısından Önemi. Karamanoğlu Mehmetbey Üniversitesi Sosyal ve Ekonomik Araştırmalar Dergisi, 2012(1), 45-52.

Durmuş, A. (2018a). Van Gölü Adalarının Ornito-Turizm Potansiyeli. II. Uluslararası Batı Asya Turizm Araştırmaları Kongresi. 27-30 Eylül, Van.

Durmuş, A. (2018b) Tendürek volkanizmasının biyoturizm potansiyeli. II. Uluslararası Batı Asya Turizm Araştırmaları Kongresi. 27-30 Eylül,Van.

Eames, J. (1991). More Selected Bird Observations From Turkey, Spring and Summer 1990. Orn. Soc. Middle East Bull. 27, 29-31.

Eken, G., Bozdoğan, M., İsfendiyaroğlu, S., Kılıı̧, D.T., ve Lise, Y. (edt.), (2006). Türkiye'nin Önemli Doğa Alanları. Doğa Derneği, Ankara, Türkiye.

Filar M., ve Biricik M. (2006). Dicle Ringing Station (SE Turkey) ringing results and seasonal bird migration dynamics in 2003-2005. Ring, 28(2), 135-145.

Frątczak, M., Sparks, T. H., Randler, C., ve Tryjanowski, P. (2020). Circadian preferences of bird watchers in Poland: do "owls" prefer watching night birds, and "larks" prefer day time ones? PeerJ,8, 86-73 https://doi.org/10.7717/

Goodfellow, D. K. (2017). Couples and avitourism: A mixedmethods study of North American bird watchers. (Unpublished PhD thesis). Lismore, NSW: Southern Cross University.

Güllü, M. (2016). Ornitoturizm Kapsamında Seyfe Gölü' nün Değerlendirilmesi. 3rd International Congress on SocialSciences, ChinatoAdriatic. October 27-30, Antalya, Turkey, ISBN-9786059885140.

IUCN, (2021).https:/ / www.iucnredlist.org/species/22683740/155514718

Karataş, M. M., veÜçeş, F. (2021). The Ornithological Diversity of the Province of Kilis. Commagene Journal of Biology, 29-34.

Kılıç, D. T., Eken, G. (2004). Türkiye'nin Önemli Kuş Alanları - 2004 Güncellemesi. Doğa Derneği, Ankara, Türkiye

Kirwan, G.M. (Compiler) (1992). Around the Region. Orn. Soc. Middle East Bull. 29, 35-48.

Kirwan, G.M.,Boyla, K.A., Castell, P., Demirci, B., Özen, M., Welch, H., veMarlow, T. (2008). The Birds of Turkey. Christopher Helm. London.

Kuş Araştırmaları Derneği (2013), http://www.dogaarastirmalari.org.tr/html Erişim Tarihi: 11.05.2021

Martins, R. P. (1989). Turkey Bird Report 1982-6. Sandgrouse, 11,1-41.

Moss, S. (2009). Birdingpast, present and future-a global view. In: Del Hoyo, J., Elliot, A., Christie, D.A. (Eds). Handbook of the Birds of the World, 4, 15-45

Neate-Clegg, M. H., Román, J. R., Demir, B., ve Şekercioğlu, Ç. H. (2019). Endangered Basra Reed-warbler (Acrocephalusgriseldis) recorded for the first time in Turkey (Aves: Acrocephalidae).Turkish Journal of Zoology,43(2), 250-253.

Nyaupane, G. P., Morais, D. B., ve Graefe, A. R. (2004). Nature tourism constraints: a cross-activity comparison. Annals of Tourism Research, 31(3), 540-555.

Özdemir, M. (1991).Turizmin Sosyal Yapı Üzerindeki Tesirleri. Türkiye Kalkınma Bankası Turizm Yıllığı. Ankara. 
Özkoç, Ö.Ü. (2020). Kars ilinde üreyen ve geçit yapan kuş türleri.TurkishJournal of Forestry,21(2), 179-187.

Pivatto, M. A. C., veSabino, J. (2005). Recomendações para minimizarimpactos à avifauna em atividades de turismo de observação de aves. AtualidadesOrnitológicas, 127, 7-11.

Radkovic, A. Z., Van Dongen, W. F., Kirao, L., Guay, P. J., veWeston, M. A. (2019). Bird watchers evoke longer escape distances than pedestrians in some African birds. Journal of Ecotourism, 18(1), 100-106.

Randler, C. (2021). Users of a citizen science platform forbird data collection differ from other bird watchers in knowledge and degree of specialization. Global Ecology and Conservation, e01580.

Sekercioglu, C. H. (2002). Impacts of birdwatching on human and avian communities. Environmental Conservation, 29, 282-289.

Seven, E. (2020). Türkiye'nin Biyoçeşitlilik Turizm Potansiyeli Üzerine Bir Değerlendirme. Journal of CurrentDebates in SocialSciences,3(2), 95-103.

Sevindi, C. (2013). Ekoturizm ve kuş gözlemciliği açısından Kuyucuk Gölü kuş cenneti (Arpaçay-Kars). Türk Coğrafya Dergisi, (61), 63-76.

Sevindi, C., ve Kaya, G. (2019). Kuş Gözlemciliği Turizmi Açsından Tortum Gölü Sulak Alanı (UzundereErzurum). Atatürk Üniversitesi Sosyal Bilimler Enstitüsü Dergisi, 23 (Özel Say1), 2203-2218.

Seyidoğlu, H. (1992). Ekonomik Terimler Ansiklopedik Sözlük. Ankara: Güzem Yayınları.

Sinha, C. C. (2001). Paperpresented during the Geography Curriculum In-service Conference. Tourism geography: issues, challenges and the changing nature of contemporary tourism. University of Western Sydney, Hawkesbury Campus.

Son, N. L. H., ve Van, N. T. (2011). Developing bird watching ecotourism combined with education and natural conservation. VNU Journal of Science: Earth andEnvironmentalSciences, 27(2), 89-97.

Şahin, G., ve Kahraman, M. (2017). Hakkâri'nin Turizme Yönelik Potansiyelleri Hakkında Bir Değerlendirme. Coğrafya Dergisi, (34), 1-21.

T.C. Orman ve Su İşleri Bakanlığı Doğa Koruma ve Milli Parklar Genel Müdürlüğü Yaban Hayatı Dairesi Başkanlığı, (2020). Türkiye Ulusal Halkalama Programı Raporu. Ankara.

Trakuş, (2021). Türkiye Kuş Türleri Listesi, Türkiye'nin Anonim Kuşları. https://www.trakus.org/kods_bird/uye/?fsx=turkiyeninkuslari, Erişim: 11.05.2021

Tutar, H., Aydoğdu, B., Elyıldırım, G., Dik, M., Sarışen, M., ve İnce, O. G. (2013). Iğdır'ın Sosyo-Ekonomik Durumu ve Uygun Yatırım Alanları.TC Serhat Kalkınma Ajansı Iğdır Yatırım Destek Ofisi Yayını, Iğdır.

Türkiye Cumhuriyeti Kültür ve Turizm Bakanlığı.https://yigm.ktb.gov.tr/TR-201121/isletme-bakanlikbelgeli-tesis-konaklama istatistikleri. / html Erişim Tarihi: 15.05.2021

Türkoğlu, M. ve Şekercioğlu, Ç. H. (2018). Iğdır'ın Kuşları. 2. Baskı. T.C. Orman ve Su İşleri Bakanlığı Doğa Koruma ve Milli Parklar Genel Müdürlüğü. 